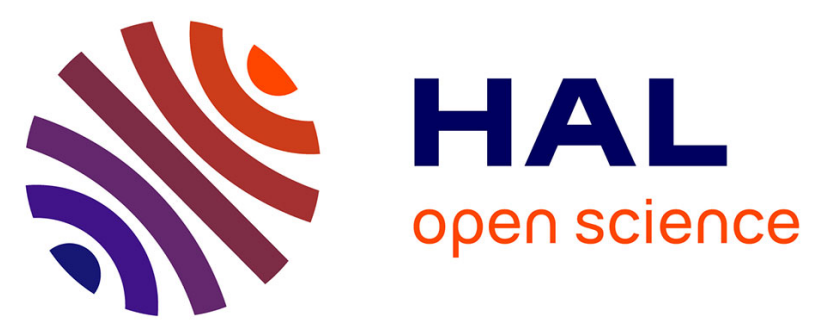

\title{
Rainbow trout resistance to bacterial cold-water disease is moderately heritable and is not adversely correlated with growth
}

J. T. Silverstein, R. L. Vallejo, Y. Palti, T. D. Leeds, C. E. Rexroad Iii, T. J. Welch, G. D. Wiens, Vincent Ducrocq

\section{To cite this version:}

J. T. Silverstein, R. L. Vallejo, Y. Palti, T. D. Leeds, C. E. Rexroad Iii, et al.. Rainbow trout resistance to bacterial cold-water disease is moderately heritable and is not adversely correlated with growth. Journal of Animal Science, 2009, 87 (2), pp.860-867. 10.2527/jas.2008-1157 . hal-02668165

\section{HAL Id: hal-02668165 https://hal.inrae.fr/hal-02668165}

Submitted on 31 May 2020

HAL is a multi-disciplinary open access archive for the deposit and dissemination of scientific research documents, whether they are published or not. The documents may come from teaching and research institutions in France or abroad, or from public or private research centers.
L'archive ouverte pluridisciplinaire HAL, est destinée au dépôt et à la diffusion de documents scientifiques de niveau recherche, publiés ou non, émanant des établissements d'enseignement et de recherche français ou étrangers, des laboratoires publics ou privés. 


\section{JOURNAL OF ANIMAL SCIENCE}

The Premier Journal and Leading Source of New Knowledge and Perspective in Animal Science

Rainbow trout resistance to bacterial cold-water disease is moderately heritable and is not adversely correlated with growth

J. T. Silverstein, R. L. Vallejo, Y. Palti, T. D. Leeds, C. E. Rexroad III, T. J. Welch, G. D. Wiens and V. Ducrocq

J ANIM SCI 2009, 87:860-867.

doi: 10.2527/jas.2008-1157 originally published online November 21, 2008

The online version of this article, along with updated information and services, is located on the World Wide Web at:

http://www.journalofanimalscience.org/content/87/3/860 
References

Citations

This article cites 30 articles, 3 of which you can access for free at: http://www.journalofanimalscience.org/content/87/3/860\#BIBL

This article has been cited by 4 HighWire-hosted articles:

http://www.journalofanimalscience.org/content/87/3/860\#otherarticles 


\title{
Rainbow trout resistance to bacterial cold-water disease is moderately heritable and is not adversely correlated with growth ${ }^{1}$
}

\author{
J. T. Silverstein, ${ }^{* 2}$ R. L. Vallejo, ${ }^{*}$ Y. Palti, ${ }^{3}$ T. D. Leeds, ${ }^{*}$ C. E. Rexroad III, ${ }^{*}$ \\ T. J. Welch, * G. D. Wiens, ${ }^{*}$ and V. Ducrocq $\dagger$ \\ *US Department of Agriculture, Agricultural Research Service, National Center for Cool and Cold Water \\ Aquaculture, 11861 Leetown Rd., Kearneysville, WV 25430; and †UR337 Institut National \\ de la Recherche Agronomique, Jouy-en-Josas 78352, France
}

\begin{abstract}
The objectives of this study were to estimate the heritabilities for and genetic correlations among resistance to bacterial cold-water disease and growth traits in a population of rainbow trout (Oncorhynchus mykiss). Bacterial cold-water disease, a chronic disease of rainbow trout, is caused by Flavobacterium psychrophilum. This bacterium also causes acute losses in young fish, known as rainbow trout fry syndrome. Selective breeding for increased disease resistance is a promising strategy that has not been widely used in aquaculture. At the same time, improving growth performance is critical for efficient production. At the National Center for Cool and Cold Water Aquaculture, reducing the negative impact of diseases on rainbow trout culture and improving growth performance are primary objectives. In 2005, when fish averaged $2.4 \mathrm{~g}$,
\end{abstract}

71 full-sib families were challenged with $F$. psychrophilum and evaluated for $21 \mathrm{~d}$. Overall survival was $29.3 \%$ and family rates of survival varied from 1.5 to $72.5 \%$. Heritability of postchallenge survival, an indicator of disease resistance, was estimated to be $0.35 \pm 0.09$. Body weights at 9 and 12 mo posthatch and growth rate from 9 to 12 mo were evaluated on siblings of the fish in the disease challenge study. Growth traits were moderately heritable, from 0.32 for growth rate to 0.61 for 12 -mo BW. Genetic and phenotypic correlations between growth traits and resistance to bacterial cold-water disease were not different from zero. These results suggest that genetic improvement can be made simultaneously for growth and bacterial cold-water disease resistance in rainbow trout by using selective breeding.

Key words: challenge test, disease resistance, genetic correlation, growth, heritability, rainbow trout

(C)2009 American Society of Animal Science. All rights reserved.

J. Anim. Sci. 2009. 87:860-867 doi:10.2527/jas.2008-1157

\section{INTRODUCTION}

Bacterial cold-water disease (BCWD), a chronic disease of rainbow trout (Oncorhynchus mykiss), is common in US rainbow trout aquaculture and is caused by Flavobacterium psychrophilum $(\boldsymbol{F p})$. This bacterium also causes acute losses in young fish, known as rainbow trout fry syndrome. Methods for prevention of BCWD

\footnotetext{
${ }^{1}$ The authors thank Eric Squires, Jim Everson, Jon Leasor, Josh Kretzer, David Payne, Chris Campbell, and Jennifer Harper (USDA, ARS, National Center for Cool and Cold Water Aquaculture, Kearneysville, WV) for technical assistance; Scott LaPatra (Clear Springs Foods, Buhl, ID) for the Flavobacterium psychrophilum strain used to challenge the fish; and Maureen Purcell (Western Fisheries Research Center, Biological Resources Discipline, US Geological Survey, Seattle, WA) for critical review of this manuscript.

${ }^{2}$ Present address: 5601 Sunnyside Ave, Rm 4-2106, Beltsville, MD 20705.

${ }^{3}$ Corresponding author: Yniv.Palti@ars.usda.gov

Received May 6, 2008.

Accepted November 13, 2008.
}

are limited, and no licensed vaccine is currently available.

There is evidence of genetic variation for resistance to $F p$ infection in salmonids. For example, Nagai et al. (2004) showed differences in susceptibility to $F p$ challenges among 3 stocks of ayu (Plecoglossus altivelis), and Henryon et al. (2005) showed significant additive genetic variation for resistance to $F p$ challenge in a Danish rainbow trout broodstock. This evidence of genetic variation in resistance to $F p$ suggests that selective breeding may improve the survival of rainbow trout.

Growth performance is another trait of primary importance to many rainbow trout producers, and selection for growth is generally included in most breeding programs (Gjerde, 2005). Typical harvest BW for rainbow trout in the United States is 400 to $500 \mathrm{~g}$, but recently the demand for larger fish has increased (National Agricultural Statistics Service, 2007)

The relationship between growth-to-harvest BW and resistance to $F p$ in rainbow trout has not been report- 
ed previously. Johansen et al. (2006) speculated that because growth and an active immune system are resource-demanding systems, an unfavorable correlation between disease resistance and growth performance may exist. However, estimates of genetic correlation between growth and general survival have typically been positive, between 0.18 and 0.37 (Fjalestad et al., 1993). Correlations between growth and specific disease resistance require empirical testing. Therefore, our objectives were to determine the phenotypic and genetic parameters for resistance to $F p$ in rainbow trout, and to determine the genetic and phenotypic relationships between resistance to $F p$ and growth.

\section{MATERIALS AND METHODS}

The institutional Animal Care and Use Committee protocol used in this research was NCCCWA Animal Care and Use Committee Protocol Number 029.

\section{Fish}

Data were from 71 full-sib families produced in January 2005 from 56 sires and 65 dams from the National Center for Cool and Cold Water Aquaculture (Kearneysville, WV) synthetic population initiated in 2002 and 2003 (Silverstein et al., 2004; Johnson et al., 2007). The 71 families were composed of 33 paternal half-sib families, 20 maternal half-sib families, and 18 full-sib families, with no maternal or paternal half sibs. The original domesticated strains that contributed to the synthetic population were 1) University of Washington, Donaldson; 2) Kamloops/Puget Sound Steelhead cross; 3) College of Southern Idaho, House Creek; and 4) Ennis NFH Shasta strain. These strains were selected because of their documented domestication. Parents from the original strains were tested and determined to be free of viral hemorrhagic septicemia virus, infectious hematopoetic necrosis virus, infectious pancreatic necrosis virus, infectious salmon anemia virus, and Renibacterium salmoninarum, the causative agent of bacterial kidney disease. Parents of the 2002 and 2003 founding populations were mated in a partly factorial design (Berg and Henryon, 1998). Approximately onehalf of the 2002 and 2003 families were $F_{1}$ crosses between different strains, and one-half were pure strains. Parents for the 2005 population were selected primarily from the 2003 population based on family growth performance, but some 3-yr-old parents from the fastest growing families of the 2002 population were also used. Pedigree data were available beginning with grandparents of fish hatched in 2005.

Eggs were fertilized over a 5-wk period between January 7, 2005, and February 8, 2005. Each full-sib group was reared in a separate incubator compartment. The hatch timing of the families was synchronized by manipulating the incubation water temperature. All egg lots hatched within a 4-d period between March 2, 2005, and March 6, 2005. After hatch, 600 randomly chosen siblings from each full-sib family were moved to separate 200-L family tanks and reared on a flow-through spring water system. Approximately $66 \mathrm{~d}$ posthatch, three 25-fish groups were weighed from each family to provide an average fish BW for each family. The average (SD) over all families was $2.4(0.3) \mathrm{g}$. One week later, between 40 and 80 fish were removed from each family tank and moved into the challenge facility (see challenge details below). Fish remaining in the family tanks were periodically culled randomly to maintain biomass densities below $50 \mathrm{~kg} / \mathrm{m}^{3}$. At 5 mo posthatch, when fish averaged 47.1 (9.9) g, between 10 and 50 fish from each full-sib family were tagged with passive integrated transponder tags (Avid, Norco, CA), and all families were combined into five 1.3-m circular tanks, each with a volume of approximately 1,000 L. Fish were divided into more tanks as they grew, to maintain biomass densities between 30 and $70 \mathrm{~kg} / \mathrm{m}^{3}$. Fish were fed most of their daily ration with Arvotec (Huutokoski, Finland) automatic feeders, and once each day, the fish were fed by hand to apparent satiation.

\section{Growth Evaluation}

Growth performance measures were individual BW at 9 and 12 mo posthatch (9BW and $\mathbf{1 2 B W}$, respectively) and growth rate, evaluated as the thermal growth coefficient (TGC) between 9 and 12 mo posthatch. The TGC provides a measure of fish growth rate on a linear scale for the typical production phase of most fish species (Iwama and Tautz, 1981; Jobling, 2003; Lankford and Weber, 2006), and is calculated in relation to degree days $(\mathrm{T} \times t)$, where $\mathrm{T}$ is water temperature in Celsius and $t$ is time in days. Calculation of TGC is as follows:

$$
\mathrm{TGC}=\left[\left(\sqrt[3]{ } \mathrm{W}_{\mathrm{f}}-\sqrt[3]{ } \mathrm{W}_{\mathrm{i}}\right) /(\mathrm{T} \times t)\right] \times 1,000,
$$

where $\mathrm{W}_{\mathrm{f}}$ is the final $\mathrm{BW}$ and $\mathrm{W}_{\mathrm{i}}$ is the initial $\mathrm{BW}$.

\section{Challenge Protocol}

The $F p$ challenge was carried out in the National Center for Cool and Cold Water Aquaculture challenge facility, where 120 eight-liter tanks were available. Forty full-sib fish were allocated to a single 8-L family tank (i.e., fish from different families were not commingled). From 42 of the 71 families, a replicate group of 40 fish was allocated; thus, 113 tanks were used. The fish were allowed $1 \mathrm{wk}$ to acclimate before challenge, and were fed daily by hand to apparent satiation. Fish were challenged with a virulent strain of Fp CSF-259-93 (Crump et al., 2001; MacLean et al., 2001) at approximately $80 \mathrm{~d}$ posthatch. The bacterial culture was prepared as described by LaFrentz et al. (2002), and $8.8 \times 10^{6} \mathrm{cfu} /$ fish was administered to each fish by intraperitoneal injection. The water temperature during challenge was $13.0 \pm 0.5^{\circ} \mathrm{C}$. Fish that died during the 21 -d period after challenge were recorded for day of mortality and 
examined for clinical signs of disease. We assumed that the longer a fish survived, the greater was its resistance to $F p$ infection (Henryon et al., 2005). Fish that did not die during the 21-d challenge were recorded as censored observations.

\section{Survival Analysis}

Time to event data (e.g., survival data) arise in several applied fields, and events (e.g., death) are generally considered "failures." A common feature of survival data is the occurrence of censored observations. Censored data arise for individuals that do not have a failure event during the predefined observation period, or for individuals arbitrarily withdrawn from the study before completion of the predefined observation period. Thus, the only knowledge from a censored record is that the individual survived for the entirety of its observation period. Survival data can be right, left, or interval censored (Klein and Moeschberger, 1999). Observations available on the failure times of $n$ individuals are assumed to be independent. Analysis of survival data that contain censored records requires statistical methods that 1) incorporate event and censored data jointly to assess the dependence of failure time on explanatory variables, and 2) appropriately specify the underlying, or baseline, hazard function (Kalbfleisch and Prentice, 2002). A classical approach to analyze censored and uncensored data jointly is to use survival analysis models, such as proportional hazards models. These can be either parametric (e.g., assuming a Weibull baseline hazard) or semiparametric, with an arbitrary hazard baseline (Cox, 1972).

However, proportional hazard models often assume that failure times are expressed on a continuous time scale, with no ties between ordered failure times (Cox, 1972; Kalbfleisch and Prentice, 2002). When survival after challenging experimental animals with a diseasecausing pathogen is evaluated for relatively short periods of time (e.g., $21 \mathrm{~d}$ ) and is measured with limited precision (i.e., observations are made infrequently), this assumption is violated. In such cases, the time scale is discrete with few classes. For these discrete data, survival analysis using standard proportional hazard models is a priori incorrect.

In this study, we had many ties between ordered failure times, because the survival data were collected for $21 \mathrm{~d}$ after exposure to the disease-causing pathogen and observations were made only once daily. Furthermore, the plot of $\ln (-\ln [S(t)])$ against $\ln (t)$, where $S(t)$ is the Kaplan-Meier survivor function and $t$ is time, did not produce a straight line (data not shown), which indicated that the Weibull distribution was not a good fit for the survival data (Kalbfleisch and Prentice, 2002). A more convenient strategy was to use the grouped data model of Prentice and Gloeckler (1978). This discrete proportional hazards model is a fully parametric one for which the baseline hazard is estimated at every discrete time point and for which the definition of hazard is modified to take into account the discrete time scale without violating the proportional hazard model (Ducrocq, 1999).

The survival times of $F p$-challenged fish were described with a grouped data model, for which the hazard function $h\left(\tau_{i} ; \mathbf{x}_{j}\right)$ within the interval $\tau_{i}=\left(t_{i-1}, t_{i}\right)$ of a particular animal $j$, characterized by a vector of explanatory $\mathbf{x}_{j}$ variables, can be written as

$$
h\left(\tau_{i} ; \mathbf{x}_{j}\right)=h_{0}\left(\tau_{i}\right) \exp \left\{\mathbf{x}_{j}^{\prime} \boldsymbol{\beta}\right\},
$$

where $h_{0}\left(\tau_{i}\right)$ is the discrete baseline hazard function and $\boldsymbol{\beta}$ is a vector of regression coefficients of the explanatory variables on survival times. An extension of the previous model is obtained by adding random effects (Ducrocq and Casella, 1996), and the resulting mixed model (also known as a frailty model) can be written as

$$
h\left(\tau_{i} ; \mathbf{x}_{j}, \mathbf{z}_{j}\right)=h_{0}\left(\tau_{i}\right) \exp \left\{\mathbf{x}_{j}^{\prime} \boldsymbol{\beta}+\mathbf{z}_{j}^{\prime} \mathbf{u}\right\}
$$

where $\mathbf{u}$ is a vector of random variables and $\mathbf{z}_{j}$ is an incidence vector.

Model Selection. Preliminary analyses to assess the significance of the random effect of challenge tank nested within family and the fixed effect of average family BW (covariate) on the response variable days to death (DTD) were performed by using REML and likelihood ratio tests implemented in the $\mathrm{R}$ statistical package from the Bioconductor Software Project (Gentleman et al., 2004). To perform these analyses, we developed an $\mathrm{R}$ script by using the statistical methods outlined by Pinheiro and Bates (2000); this R script is available online (http://www.ars.usda.gov/Research/ docs.htm?docid $=8033)$. Both effects were significant $(P$ $<0.05)$ in the preliminary analyses and were therefore included in the survival analysis models.

Frailty Models. Bayesian analysis of the frailty models developed by Ducrocq and Casella (1996) can be applied to the grouped data model (Prentice and Gloeckler, 1978) for discrete data (Ducrocq, 1999), and this method was implemented in the Survival Kit Version 3.12 program (Ducrocq and Sölkner, 1998) by using the following discrete failure time frailty models.

- Animal model:

$$
h\left(\tau_{i} ; \mathbf{x}_{j}, \mathbf{z}_{1 j}, \mathbf{z}_{2 k}\right)=h_{0}\left(\tau_{i}\right) \exp \left\{\mathbf{x}_{j}^{\prime} \boldsymbol{\beta}+\mathbf{z}_{1 j}^{\prime} a+\mathbf{z}_{2 k}^{\prime} \mathbf{r}\right\}
$$

where $\boldsymbol{\beta}_{j}$ is a vector for the fixed animal BW covariate, $\mathbf{a}$ is the vector of random animal genetic effects with the assumption $\mathbf{a} \sim \operatorname{MVN}\left(0, \mathbf{A} \sigma_{\text {animal }}^{2}\right)$, where $\mathbf{A}$ is the numerator relationship matrix, $\mathbf{r}$ is the vector of ran- 
dom tank or family effects, and $\mathbf{x}_{j}, \mathbf{z}_{1 j}$, and $\mathbf{z}_{2 k}$ are incidence matrices.

- Sire-dam model:

$$
h\left(\tau_{i} ; \mathbf{x}_{j}, \mathbf{z}_{1 j}, \mathbf{z}_{2 k}\right)=h_{0}\left(\tau_{i}\right) \exp \left\{\mathbf{x}_{j}^{\prime} \boldsymbol{\beta}+\mathbf{z}_{1 j}^{\prime} \mathbf{s}+\mathbf{z}_{2 k}^{\prime} \mathbf{r}\right\},
$$

where $\boldsymbol{\beta}_{j}$ is a vector for the fixed animal BW covariate, $\mathbf{s}$ is the vector of random sire-dam effects, $\mathbf{r}$ is the vector of random tank or family effects, and $\mathbf{x}_{j}, \mathbf{z}_{1 j}$, and $\mathbf{z}_{2 k}$ are incidence matrices.

Animal $\left(\sigma_{\text {animal }}^{2}\right)$ and sire-dam $\left(\sigma_{\text {sire-dam }}^{2}\right)$ variance components and EBV were estimated by using the Bayesian approach outlined by Ducrocq and Casella (1996). The reliability $(R)$ for survival EBV when using the sire-dam model was estimated as

$$
R=1-\left(S E P^{2} / 4 \times \sigma_{\text {sire-dam }}^{2}\right),
$$

where $S E P^{2}$ is the squared SE of EBV.

Heritability of Survival. The effective heritability of survival was estimated from both models by using expressions modified from Yazdi et al. (2002).

- Animal model:

$$
h^{2}=\sigma_{\text {animal }}^{2} /\left(1+\frac{1}{4} \sigma_{\text {animal }}^{2}\right),
$$

- Sire-dam model:

$$
h^{2}=2 \sigma_{\text {fam }}^{2} /\left(1+\sigma_{\text {sire-dam }}^{2}\right) .
$$

where fam is for full-sib families.

\section{Growth Analysis}

For growth data, the MTDFREML software developed by Boldman et al. (1995) was used to analyze the data, using animal and sire-dam models for an observation vector $\mathbf{y}$ :

$$
\mathbf{y}=\mathbf{X} \boldsymbol{\beta}+\mathbf{Z}_{1} \mathbf{a}+\mathbf{Z}_{2} \mathbf{u}+\mathrm{e},
$$

where $\boldsymbol{\beta}$ is a vector of fixed effects, $\mathbf{a}$ is a vector of random animal or sire-dam genetic effects, $\mathbf{u}$ is a vector of random effects of family tank before tagging individuals and pooling families into larger tanks, and $\mathbf{X}$, $\mathbf{Z}_{1}$, and $\mathbf{Z}_{2}$ are design matrices. Fixed effects included rearing tank after tagging and sex. Using these models, we obtained estimates of genetic ( $V_{\text {animal }}$ and $\left.V_{\text {sire-dam }}\right)$, common environment $\left(V_{\text {familytank }}\right)$, residual $\left(V_{R}\right)$, and phenotypic variances $\left(V_{A}+V_{\text {familytank }}+V_{R}\right)$.

\section{Genetic and Phenotypic Correlations}

The EBV were derived from animal and sire-dam models for survival, 9BW, 12BW, and TGC. Genetic correlations among growth traits were estimated from 2-trait animal models in MTDFREML. Genetic correlations between growth traits and survival were estimated by using 2 approaches. First, family mean EBV were calculated from the animal model EBV, and Pearson correlations between family mean EBV were calculated. Correlations were weighted by the variance of the growth data attributable to differences in the number of individuals sampled per family for growth traits. Second, Pearson correlations between parent EBV from sire-dam models were calculated. Phenotypic correlations among growth traits were estimated from MTDFREML. Phenotypic correlations between growth and DTD were estimated as Pearson correlations between family mean growth and DTD phenotypic data.

\section{RESULTS}

In this experiment, 4,656 fish were challenged and 1,350 survived until the termination of the study (i.e., $71 \%$ of the fish challenged with $F p$ died during the 21-d challenge), with a mean DTD of $8.1 \mathrm{~d}$. Mortality was low through d $4\left(1.6 \% \cdot \mathrm{d}^{-1}\right)$, and then increased to more than $5 \% \cdot \mathrm{d}^{-1}$ through $\mathrm{d} 9$, resulting in more than $54 \%$ mortality by d 9 (Figure 1). One major peak of mortality was centered at d 6 , with a smaller secondary increase at d 13 to 14 . At d 18, mortality declined to less than $1 \% \cdot \mathrm{d}^{-1}$.

There was substantial variation among full-sib families for mortality rates, which ranged from 27.5 to 98.5\% (Figure 2). Survival of the $F p$ challenge had a clear additive genetic component; survival heritability estimates were $0.35 \pm 0.09$ and $0.43 \pm 0.03$ from the animal and sire-dam models, respectively. Variance attributable to tank within families accounted for only $1.6 \%$ of the phenotypic variance (data not shown). Body weight at the time of challenge had a significant effect on survival. Resistance to BCWD increased with increasing $\mathrm{BW}$; each 1-g increase in BW conferred a 0.7 \pm 0.2 -d increase in DTD $(P<0.001)$.

Heritability estimates from animal models for 9BW, $12 \mathrm{BW}$, and TGC were $0.59,0.61$, and 0.32 , respectively (Table 1). The common environmental effect (i.e., family tank before tagging) accounted for 5 and $2 \%$ of variation in $9 \mathrm{BW}$ and $12 \mathrm{BW}$, respectively.

Genetic correlations between survival and 9BW, $12 \mathrm{BW}$, and TGC were $\leq 0.10$ (absolute value) and were not different from 0 when estimated by using family mean EBV from the animal models (Table 2). Similarly, these genetic correlations were $\leq 0.09$ (absolute value) when estimated by using parental EBV from the sire-dam models (data not shown). Phenotypic correlations between survival and growth traits were weak and were not different from 0 (Table 2). Genetic and 


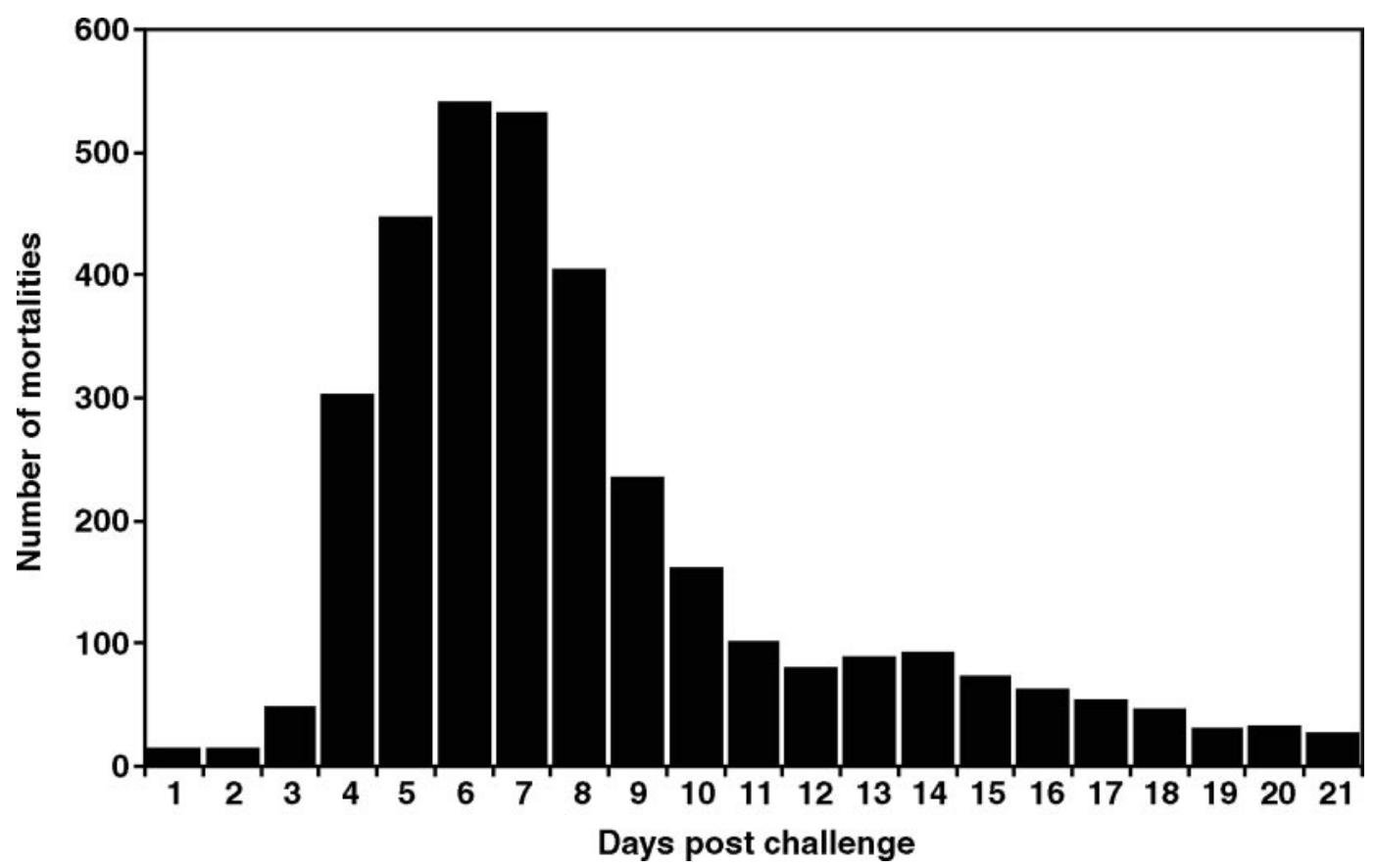

Figure 1. Daily mortality over time. Each bar represents the number of mortalities for the days after challenge. In 2005, when fish averaged $2.4 \mathrm{~g}, 71$ full-sib families were challenged with Flavobacterium psychrophilum, and survival was evaluated for $21 \mathrm{~d}$.

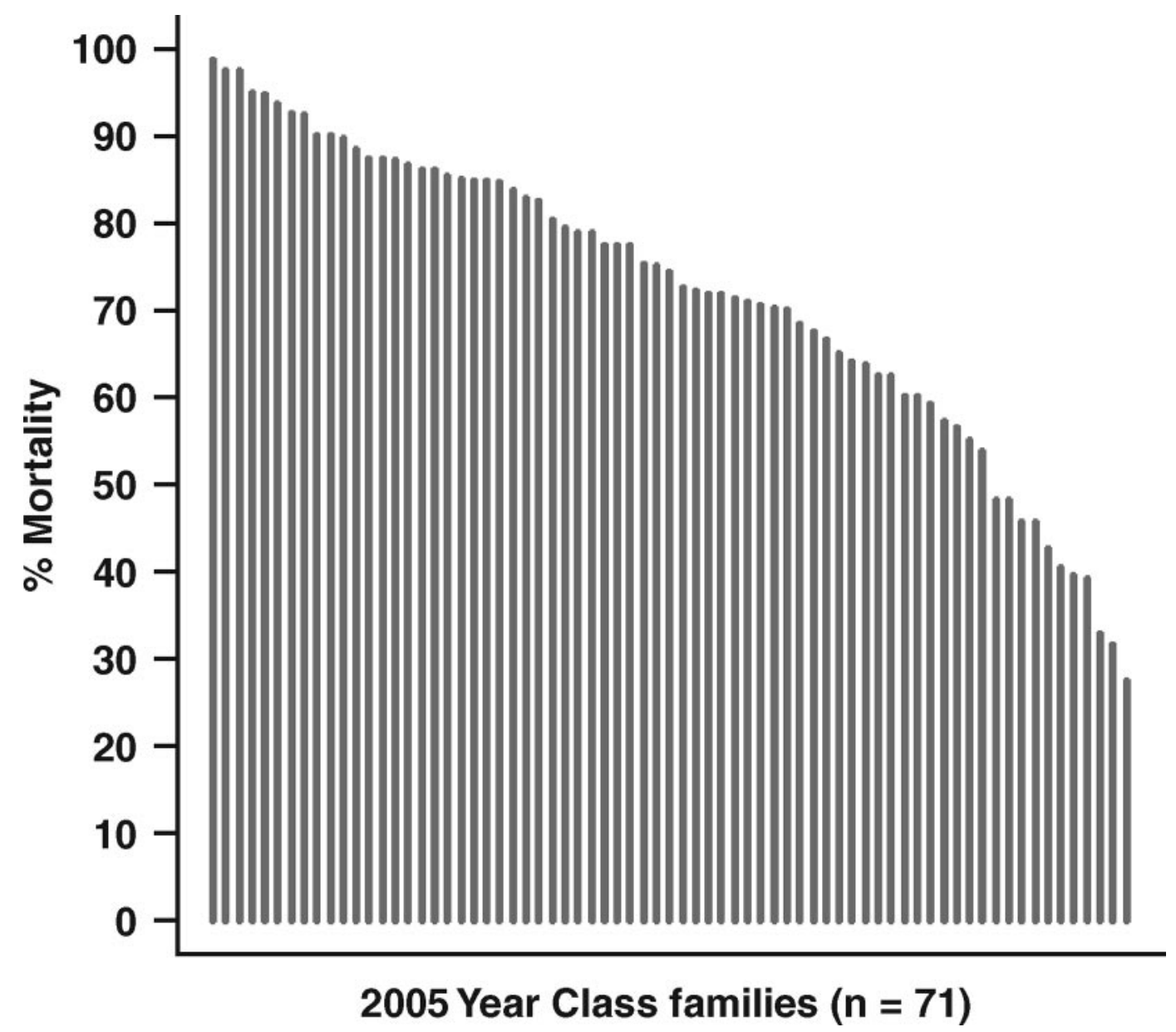

Figure 2. Percentage mortality of the groups challenged. Replicated families are represented by the average of the 2 replicates. In 2005 , when fish averaged $2.4 \mathrm{~g}, 71$ full-sib families were challenged with Flavobacterium psychrophilum, and survival was evaluated for $21 \mathrm{~d}$. 
Table 1. Sample sizes (n), means and their SD (g), and heritabilities and their SE for growth traits

\begin{tabular}{lccccc}
\hline \hline Trait & $\mathrm{n}$ & Mean & $\mathrm{SD}$ & $\mathrm{h}^{2}$ & $\mathrm{SE}$ \\
\hline 9BW $^{1}$ & 1,409 & 595.2 & 146.7 & 0.59 & 0.08 \\
12BW $^{1}$ & 1,357 & $1,131.1$ & 282.0 & 0.61 & 0.09 \\
TGC $^{2}$ & 1,357 & 2.07 & 0.49 & 0.32 & 0.07 \\
\hline
\end{tabular}

${ }^{1} 9 \mathrm{BW}$ and $12 \mathrm{BW}=\mathrm{BW}$ at 9 and 12 mo posthatch, respectively.

${ }^{2} \mathrm{TGC}=$ thermal growth coefficient between 9 and 12 mo posthatch [units are grams divided by degree days $(\mathrm{T} \times t)$, where $\mathrm{T}$ is water temperature in Celsius and $t$ is time in days].

phenotypic correlations between 9BW and 12BW were large $(\geq 0.86)$, whereas correlations of $9 \mathrm{BW}$ and $12 \mathrm{BW}$ with TGC were $\leq 0.69$ (Table 3). Correlations between $12 \mathrm{BW}$ and TGC were considerably stronger than correlations between 9BW and TGC.

\section{DISCUSSION}

The potential to improve a population of rainbow trout for resistance to BCWD through selective breeding depends first on there being an additive genetic component to variation in resistance. Furthermore, the value of using selective breeding for this trait is conditioned by how selection for BCWD resistance may affect other traits. In this study, we found a moderate heritability for resistance to BCWD, measured as DTD, and no significant correlation with growth to market sizes. These findings are encouraging because they suggest that selection to improve BCWD resistance will not be antagonistic to improved growth; thus, both traits can be improved simultaneously.

Additive genetic variation for resistance to specific pathogens has been reported for many animals, including fish (Chevassus and Dorson, 1990; Van Muiswinkel et al., 1999; Bishop and Morris, 2007). In particular, Henryon et al. (2005) also found resistance to $F p$ to be heritable. Nevertheless, their estimates were considerably less, at 0.07 compared with our current estimate of 0.35 . In both studies, intraperitoneal injection was the route of pathogen delivery. Differences in fish size, strain of the pathogen, and other environmental differences could be responsible for the difference in estimates. Additionally, any heritability estimate is particular to a population and environment, and the response to this challenge may have had a stronger genetic basis than the challenge conducted by Henryon et al. (2005). The difference between heritability estimates from the animal and sire-dam models $(0.35$ and 0.43 , respectively) provides an idea of the magnitude of nonadditive genetic effects on the inheritance of BCWD resistance, although the data structure was not ideal to interpret the differences in variances.

The effect of $\mathrm{BW}$ at the time of challenge on resistance to BCWD was positive in this study, and a similar conclusion was reached by Henryon et al. (2005); however, the BW data from the 2 studies did not measure exactly the same thing. In the current study, mean BW of each full-sib family 1 wk before challenge was used as a covariate in the statistical model. In the study by Henryon et al. (2005), each fish was weighed when it was removed from the tank after death or at the end of the experiment, and these data were included as a covariate. In both cases, fish BW was positively related to resistance, suggesting that greater BW at pathogen exposure confers some advantage.

In our mating design, some of the families were paternal half sibs, some were maternal half sibs, and some did not have half sibs. This design required us to estimate family breeding values as mean of the EBV of the animals to estimate genetic correlations between postchallenge survival and growth traits. However, we also used the sire-dam model to estimate breeding values for growth traits by using MTDFREML and to estimate postchallenge survival by using Survival Kit, which enabled us to estimate reliabilities of the parental EBV. The reliabilities of the sire-dam EBV averaged $0.73,0.73$, and 0.60 for $9 \mathrm{BW}, 12 \mathrm{BW}$, and TGC, respectively, and 0.88 for survival (data not shown). These large accuracies suggest that our estimates of 0 for genetic correlations between growth and survival are good approximations, and support our results when using EBV from the animal models.

Genetic correlations between resistance to BCWD and BW at later ages (i.e., 9 and 12 mo posthatch) and growth rate have not been reported previously. The nonsignificant correlations found here are promising for selective breeding, because selection for improvement in one trait should not have antagonistic effects on the other. A favorable genetic correlation between Fp resistance and growth would be desirable, because selection for either trait would result in improvement in the other.

Table 2. Approximate genetic $\left(\mathrm{r}_{\mathrm{g}}\right)$ and phenotypic $\left(\mathrm{r}_{\mathrm{p}}\right)$ correlations between postchallenge survival and growth traits ${ }^{1}$

\begin{tabular}{|c|c|c|}
\hline Trait & $r_{g}$ & $r_{p}$ \\
\hline $\begin{array}{l}9 \mathrm{BW}^{2} \\
12 \mathrm{BW}^{2} \\
\mathrm{TGC}^{3}\end{array}$ & $\begin{array}{r}-0.09(-0.31 \text { to } 0.15) \\
-0.10(-0.33 \text { to } 0.13) \\
0.09(-0.15 \text { to } 0.31)\end{array}$ & $\begin{array}{r}0.01(-0.08 \text { to } 0.09) \\
-0.06(-0.07 \text { to } 0.05) \\
-0.13(-0.39 \text { to } 0.22)\end{array}$ \\
\hline
\end{tabular}


Table 3. Genetic (below diagonal) and phenotypic (above diagonal) correlations among BW and thermal growth coefficient (TGC) traits

\begin{tabular}{lccc}
\hline \hline Item & 9 -mo BW & 12 -mo BW & TGC \\
\hline $9 \mathrm{BW}^{1}$ & & 0.86 & 0.15 \\
$12 \mathrm{BW}^{1}$ & $0.93 \pm 0.02$ & & 0.62 \\
TGC $^{2}$ & $0.39 \pm 0.14$ & $0.69 \pm 0.08$ & \\
\hline
\end{tabular}

${ }^{1} 9 \mathrm{BW}$ and $12 \mathrm{BW}=\mathrm{BW}$ at 9 and 12 mo posthatch, respectively.

${ }^{2} \mathrm{TGC}=$ thermal growth coefficient between 9 and 12 mo posthatch [units are grams divided by degree days $(\mathrm{T} \times t)$, where $\mathrm{T}$ is water temperature in Celsius and $t$ is time in days]

A weak and nonsignificant correlation between resistance to BCWD and growth means that to improve both traits would require selection pressure on each trait. The method expected to give the most rapid improvement in merit is simultaneous selection by using an index incorporating economic weights and heritabilities for each trait, and genetic and phenotypic correlations between the traits (Falconer and Mackay, 1996).

Favorable genetic correlations between general survival and growth were previously observed in salmon and trout. Estimates of correlation between general survival and fingerling growth were 0.23 to 0.37 (reviewed in Gjedrem, 2000); however, correlations between growth and resistance to specific diseases are less consistent.

The relationship between growth and disease resistance is not consistent among different species or among different diseases. Work in the shrimp (Penaeus vannamei) has shown a favorable genetic correlation $(\sim 0.4)$ between general survival and growth (Gitterle et al., 2005a); however, an unfavorable correlation (between -0.55 and -0.64 ) was found between growth and resistance to white spot syndrome virus (Gitterle et al., 2005b). Gjedrem et al. (1991) found a correlation of 0.3 between vibriosis and growth among matched groups of fingerling Atlantic salmon (Salmo salar), whereas we found a correlation near 0 for 2.4-g rainbow trout challenged with $F p$ and compared with their growth rate to market size.

The heritabilities of $9 \mathrm{BW}$ and $12 \mathrm{BW}$ and growth rate between 9 and 12 mo were moderate to high and were somewhat greater than previous estimates for rainbow trout at similar ages. Other estimates of BW heritability were between 0.48 and 0.55 (Elvingson and Johansson, 1993) and between 0.15 and 0.38 (Kause et al., 2006). The differences in growth rates among families and the moderate to high heritabilities suggest considerable potential for growth improvement in this population.

In summary, we demonstrated that rainbow trout survival after $F p$ injection challenge was a moderately heritable trait in our broodstock population. These results have favorable implications for selective breeding for increased disease resistance and have provided an important experimental resource for investigation into the mechanistic basis of immunity to this pathogen. In 2 additional studies, we demonstrated a positive corre- lation between family survival and average spleen size (Hadidi et al., 2008). In addition, we reported an association between survival and 2 microsatellites (OMM3089 and OMM1189) that map near the major histocompatibility IB region (Johnson et al., 2008). Thus, the fish crosses identified in this study are likely to continue to provide an important experimental resource. However, it is important to recognize that several caveats remain. All our work has used a single bacterial clone isolated from F. psychrophilum strain CSF 259-93 and all challenge work has used injection challenge. Further laboratory-based experiments and field trials are underway to determine the relevance of these findings to performance under farm conditions.

\section{LITERATURE CITED}

Berg, P., and M. Henryon. 1998. A comparison of mating designs for inference on genetic parameters in fish. Proc. 6th World Congr. Genet. Appl. Livest. Prod. 27:115-118.

Bishop, S., and C. Morris. 2007. Genetics of disease resistance in sheep and goats. Small Rumin. Res. 70:48-59.

Boldman, K. G., L. A. Kriese, L. D. Van Vleck, C. P. Van Tassell, and S. D. Kachman. 1995. A manual for use of MTDFREML. A set of programs to obtain estimates of variances and covariances [draft]. US Government Printing Office, Washington, DC.

Chevassus, B., and M. Dorson. 1990. Genetics of resistance to disease in fishes. Aquaculture 85:83-107.

Cox, D. R. 1972. Regression models and life-tables. J. R. Statist. Soc. B 34:187-220.

Crump, E. M., M. B. Perry, S. C. Clouthier, and W. W. Kay. 2001. Antigenic characterization of the fish pathogen Flavobacterium psychrophilum. Appl. Environ. Microbiol. 67:750-759.

Ducrocq, V. 1999. Extension of survival analysis to discrete measures of longevity. Pages 41-47 in 4th Int. Workshop on Genetic Improvement of Functional Traits in Cattle - Longevity. Interbull, Jouy-en-Josas, France.

Ducrocq, V., and G. Casella. 1996. A Bayesian analysis of mixed survival models. Genet. Sel. Evol. 28:505-529.

Ducrocq, V., and J. Sölkner. 1998. The Survival Kit-A FORTRAN package for the analysis of survival data. Proc. 6th World Congr. Genet. Appl. Livest. Prod. 27:447-448.

Elvingson, P., and K. Johansson. 1993. Genetic and environmental components of variation in body traits of rainbow trout (Oncorhynchus mykiss) in relation to age. Aquaculture 118:191204.

Falconer, D. S., and T. F. C. Mackay. 1996. Introduction to Quantitative Genetics. 4th ed. Longman Group Ltd., Essex, UK.

Fjalestad, K. T., T. Gjedrem, and B. Gjerde. 1993. Genetic improvement of disease resistance in fish: An overview. Aquaculture 111:65-74.

Gentleman, R. C., V. J. Carey, D. M. Bates, B. Bolstad, M. Dettling, S. Dudoit, B. Ellis, L. Gautier, Y. Ge, J. Gentry, K. Hornik, T. Hothorn, W. Huber, S. Iacus, R. Irizarry, F. Leisch, C. Li, M. Maechler, A. J. Rossini, G. Sawitzki, C. Smith, G. Smyth, L. Tierney, J. Y. Yang, and J. Zhang. 2004. Bioconductor: Open software development for computational biology and bioinformatics. Genome Biol. 5:R80.

Gitterle, T., M. Rye, R. Salte, J. Cock, H. Johansen, C. Lozano, J. Arturo Suárez, and B. Gjerde. 2005a. Genetic (co)variation in harvest body weight and survival in Penaeus (litopenaeus) vannamei under standard commercial conditions. Aquaculture 243:83-92.

Gitterle, T., R. Salte, B. Gjerde, J. Cock, H. Johansen, M. Salazar, C. Lozano, and M. Rye. 2005b. Genetic (co)variation in resistance to white spot syndrome virus (WSSV) and harvest weight in Penaeus (litopenaeus) vannamei. Aquaculture 246:139-149. 
Gjedrem, T. 2000. Genetic improvement of cold-water fish species. Aquac. Res. 31:25-33.

Gjedrem, T., R. Salte, and H. M. Gjoen. 1991. Genetic variation in susceptibility of Atlantic salmon to furunculosis. Aquaculture 97:1-6.

Gjerde, B. 2005. Design of fish breeding programs. Pages 173-195 in Selection and Breeding Programs in Aquaculture. T. Gjedrem, ed. Springer, New York, NY.

Hadidi, S., G. W. Glenney, T. J. Welch, J. T. Silverstein, and G. D. Wiens. 2008. Spleen size predicts resistance of rainbow trout to Flavobacterium psychrophilum challenge. J. Immunol. 180:4156-4165.

Henryon, M., P. Berg, N. J. Olesen, T. E. Kjær, W. J. Slierendrecht, A. Jokumsen, and I. Lund. 2005. Selective breeding provides an approach to increase resistance of rainbow trout (Onchorhynchus mykiss) to the diseases, enteric redmouth disease, rainbow trout fry syndrome, and viral haemorrhagic septicaemia. Aquaculture 250:621-636.

Iwama, G. K., and A. F. Tautz. 1981. A simple growth model for salmonids in hatcheries. Can. J. Fish. Aquat. Sci. 38:649-656.

Jobling, M. 2003. The thermal growth coefficient (TGC) model of fish growth: A cautionary note. Aquac. Res. 34:581-584.

Johansen, K. A., W. M. Sealey, and K. Overturf. 2006. The effects of chronic immune stimulation on muscle growth in rainbow trout. Comp. Biochem. Phys. B: Biochem. Mol. Biol. 144:520-531.

Johnson, N., R. L. Vallejo, C. E. Rexroad III, E. M. Hallerman, and Y. Palti. 2007. Development and evaluation of a new microsatellite multiplex system for parental allocation and management of rainbow trout broodstocks. Aquaculture 266:53-62.

Johnson, N., R. Vallejo, J. Silverstein, T. Welch, G. Wiens, E. Hallerman, and Y. Palti. 2008. Suggestive association of major histocompatibility IB genetic markers with resistance to bacterial cold water disease in rainbow trout (Oncorhynchus mykiss). Mar. Biotechnol. 10:429-437.

Kalbfleisch, J. D., and R. L. Prentice. 2002. The Statistical Analysis of Failure and Time Data. 2nd ed. John Wiley and Sons, Hoboken, NJ.

Kause, A., D. Tobin, D. F. Houlihan, S. A. M. Martin, E. A. Maantysaari, O. Ritola, and K. Ruohonen. 2006. Feed efficiency of rainbow trout can be improved through selection: Different genetic potential on alternative diets. J. Anim. Sci. 84:807-817.
Klein, J. P., and M. L. Moeschberger. 1999. Survival Analysis: Techniques for Censored and Truncated Data. 3rd ed. Springer, New York, NY.

LaFrentz, B. R., S. E. LaPatra, G. R. Jones, J. L. Congleton, B. Sun, and K. D. Cain. 2002. Characterization of serum and mucosal antibody responses and relative percent survival in rainbow trout, Oncorhynchus mykiss (Walbaum), following immunization and challenge with Flavobacterium psychrophilum. J. Fish Dis. 25:703-713.

Lankford, S. E., and G. M. Weber. 2006. Associations between plasma growth hormone, insulin-like growth factor-I, and cortisol with stress responsiveness and growth performance in a selective breeding program for rainbow trout. N. Am. J. Aquac. 68:151-159

MacLean, L. L., E. Vinogradov, E. M. Crump, M. B. Perry, and W. W. Kay. 2001. The structure of the lipopolysaccharide Oantigen produced by Flavobacterium psychrophilum (259-93). Eur. J. Biochem. 268:2710-2716.

Nagai, T., T. Tamura, Y. Iida, and T. Yoneji. 2004. Differences in susceptibility to Flavobacterium psychrophilum among three stocks of ayu, Plecoglossus altivelis. Fish Pathol. 39:159-164.

National Agricultural Statistics Service. 2007. Trout Production. http://usda.mannlib.cornell.edu/usda/current/TrouProd/ TrouProd-02-26-20071.pdf Accessed Dec. 5, 2007.

Pinheiro, J., and D. Bates. 2000. Mixed-Effects Models in S and SPLUS. 1st ed. Springer, New York NY.

Prentice, R. L., and L. A. Gloeckler. 1978. Regression analysis of grouped survival data with application to breast cancer data. Biometrics 34:57-67.

Silverstein, J. T., C. E. Rexroad III, and T. L. King. 2004. Genetic variation measured by microsatellites among three strains of domesticated rainbow trout (Oncorhynchus mykiss, Walbaum). Aquac. Res. 35:40-48.

Van Muiswinkel, W. B., G. F. Wiegertjes, and R. J. M. Stet. 1999. The influence of environmental and genetic factors on the disease resistance of fish. Aquaculture 172:103-110.

Yazdi, M. H., P. M. Visscher, V. Ducrocq, and R. Thompson. 2002. Heritability, reliability of genetic evaluations and response to selection in proportional hazards models. J. Dairy Sci. 85:1563-1577. 